\title{
The phytoestrogen genistein suppresses cell-mediated immunity in mice
}

\author{
S Yellayi ${ }^{1}$, M A Zakroczymski ${ }^{1}$, V Selvaraj ${ }^{1}$, V E Valli ${ }^{2}$, \\ V Ghanta ${ }^{1}$, W G Helferich ${ }^{3,4}$ and P S Cooke ${ }^{1,4}$ \\ ${ }^{1}$ Department of Veterinary Biosciences, University of Illinois, Urbana, Illinois 61802, USA \\ ${ }^{2}$ Department of Veterinary Pathobiology, University of Illinois, Urbana, Illinois 61802, USA \\ ${ }^{3}$ Food Science and Human Nutrition, University of Illinois, Urbana, Illinois 61802, USA \\ ${ }^{4}$ Division of Nutritional Sciences, University of Illinois, Urbana, Illinois 61802, USA \\ (Requests for offprints should be addressed to P Cooke, Department of Veterinary Biosciences, University of Illinois, 2001 S. Lincoln Avenue, Urbana, \\ Illinois 61802, USA; Email: p-cooke@uiuc.edu) \\ (S Yellayi is now at School of Veterinary Medicine, 3800 Spruce Street, University of Pennsylvania, Philadelphia, Pennsylvania 19104, USA)
}

\begin{abstract}
The soy phytoestrogen, genistein, induces thymic atrophy when administered to ovariectomized mice by injection or in the diet. Injected genistein also causes decreased humoral immunity, but the effects of genistein on cellmediated immunity have not been addressed. Here we examined effects of injected and dietary genistein on cell-mediated immune responses. Female C57BL/6 mice (25- to 27-days-old) were ovariectomized, then placed on phytoestrogen-free feed 5 days later. Seven days after ovariectomy, they were given daily subcutaneous injections of either dimethylsulfoxide (DMSO) or genistein (8, $20,80 \mathrm{mg} / \mathrm{kg}$ ) for 28 days; some mice were given $80 \mathrm{mg} /$ $\mathrm{kg}$ genistein plus the anti-estrogen ICI 182,780 (5 mg/ $\mathrm{kg} /$ week). Cell-mediated immune response was tested by analyzing the delayed-type hypersensitivity (DTH) response to a hapten, 4-hydroxy-3-nitrophenyl acetyl succinimide (NP-O-SU), at the end of treatment. Reversibility of the effects of genistein was tested by measuring the DTH response in mice that were given genistein $(20$ or $80 \mathrm{mg} / \mathrm{kg}$ ) for 28 days, then allowed to recover for 28 days. To determine if dietary genistein could affect cell-mediated
\end{abstract}

immunity, mice ovariectomized as above were fed genistein at 0,1000 or 1500 parts per million (ppm) for 28 days. There was a $46-67 \%$ decrease in the DTH response in the footpads of mice injected with $8-80 \mathrm{mg} / \mathrm{kg}$ genistein compared with controls $(P<0 \cdot 05$ vs control for all treatment groups); these effects were reversible. On histopathological examination of the feet, there was decreased cell infiltration in genistein-treated animals compared with controls, and the numbers of $\mathrm{CD}^{+}$and $\mathrm{CD} 8^{+} \mathrm{T}$ cells in popliteal lymph nodes were reduced. The effects of genistein are mediated through both estrogen receptor (ER) and non-ER pathways, as the anti-estrogen ICI 182,780 only partially blocked the effects of genistein on the DTH response. Dietary genistein (1000 or 1500 ppm) decreased cellmediated immunity while producing serum genistein concentrations in the physiological range for humans under certain nutritional conditions. Further work is needed to determine if dietary genistein and phytoestrogen exposure can produce effects on cell-mediated immunity in humans or other animals under various nutritional conditions.

Journal of Endocrinology (2003) 176, 267-274

\section{Introduction}

Genistein is an isoflavone present in high quantities in soy. Like other phytoestrogens, genistein binds to the classical estrogen receptor (ER), ER $\alpha$, and produces increases in parameters such as uterine weight (reviewed in Whitten \& Patisaul 2001). In addition, genistein binds to the recently discovered second estrogen receptor, ER $\beta$, with higher affinity than for $\mathrm{ER} \alpha$, which has led to the suggestion that genistein signaling through ER $\beta$ may be important for its biological actions (Kuiper et al. 1997, 1998).

Soy and products derived from soy, such as soy protein and isoflavone supplements, are being consumed in increasing quantities by humans. Similarly, high quantities are used as a feed ingredient for laboratory, companion and food animals (Brown \& Setchell 2001, Court \& Freeman 2002). Soy consumption has been suggested to have a variety of human health benefits based on laboratory and epidemiological evidence (reviewed in Patisaul \& Whitten 1999). Many of these potential health benefits may be due to the soy isoflavones genistein and daidzein (reviewed in Adlercreutz 1998, Patisaul \& Whitten 1999). However, there has been concern that the estrogenic effects of these compounds might have deleterious effects in some situations. For example, consumption of high levels of soy by captive cheetahs was linked to infertility 
and a veno-occlusive disease in these animals (Setchell et al. 1987), and Sharpe et al. (2002) have recently shown that consumption of soy formula by neonatal marmosets led to decreases in serum testosterone. The high levels and ubiquity of soy consumption in certain human and animal populations emphasize the need to more fully understand the actions of the isoflavones.

We have previously shown that injected and dietary genistein administered to mice can produce decreases in thymic weight of up to $80 \%$; dietary genistein also produced thymic atrophy (Yellayi et al. 2002). In addition, animals injected with genistein had decreased overall numbers of thymocytes. These thymic changes were accompanied by decreases in relative percentages of certain $\mathrm{T}$ cells in the spleen and a systemic lymphocytopenia.

The adaptive immune system involves both humoral and cell-mediated immunity. Humoral immunity results from the coordinated actions of $\mathrm{CD} 4^{+} \mathrm{T}$ cells and B cells, and injected genistein produced a dose-dependent suppression of humoral immunity (Yellayi et al. 2002). In contrast, cell-mediated immunity involves $\mathrm{CD}^{+}$and $\mathrm{CD}^{+} \mathrm{T}$ cells, which are both reduced in the thymus by genistein injection (Yellayi et al. 2002). These cell types, as well as macrophages, express estrogen receptor (Cohen et al. 1983, Gulshan et al. 1990, Suenaga et al. 1998), and cell-mediated immunity is decreased by estrogen in mice (Holmdahl \& Jansson 1988, Salem et al. 2000) and women (Hoek et al. 1995), raising the possibility that genistein could have similar effects. The objective of the present study was to determine whether genistein had effects on cell-mediated immunity. Our results show that injected and dietary genistein suppress cell-mediated immunity, and dietary genistein does so even when fed in amounts that produce serum genistein levels commonly obtained in both humans and animals.

\section{Materials and Methods}

\section{Animals}

Female C57BL/6 mice were obtained from Harlan (Indianapolis, IN, USA) or produced in our colony using parental stock purchased from Harlan. Teklad rodent chow and tap water were available ad libitum. All animals were housed under controlled lighting (12 h light, $12 \mathrm{~h}$ darkness) and temperature $\left(21-22^{\circ} \mathrm{C}\right)$ conditions and maintained in accordance with the NIH Guide for the Care and Use of Laboratory Animals. All experiments were approved by the Institutional Animal Care and Use Committee of the University of Illinois.

\section{Animal treatments}

Mice (25- to 27-days-old) were ovariectomized one week before initiation of genistein treatment to minimize circulating $17 \beta$-estradiol $\left(E_{2}\right)$ levels. They were fed a casein-based phytoestrogen-free diet (AIN-93 G), avail- able ad libitum, starting 2 days before injections began. Mice (32- to 34-days-old when injected) were given one subcutaneous injection/day for 28 days of $0.02 \mathrm{ml} \mathrm{di-}$ methylsulfoxide (DMSO) (control) or genistein (Indofine Chemicals, Somerville, NJ, USA) at 8,20 or $80 \mathrm{mg} / \mathrm{kg} /$ day. Some animals were also given genistein $(80 \mathrm{mg} / \mathrm{kg} /$ day) in combination with the anti-estrogen ICI 182,780 (AstraZeneca, Macclesfield, Cheshire, UK; 5 mg/week/ animal). We have previously shown that this dose of ICI 182,780 totally blocks the uterotropic effects of the genistein dosage administered here (Yellayi et al. 2002).

To determine the effects of dietary genistein on cellmediated immunity, we fed 32- to 34-day-old, ovariectomized mice for 28 days with the phytoestrogen-free AIN-93 G diet (control), available ad libitum, or this diet supplemented with 1000 or 1500 parts per million (ppm) genistein.

\section{Cell-mediated immune responses}

Cell-mediated immunity was tested by analyzing the delayed-type hypersensitivity (DTH) response to a hapten, 4-hydroxy-3-nitrophenyl acetyl succinimide (NP-O-SU), at the end of the genistein treatment period. Animals were primed by injecting a sensitizing dose of $50 \mu \mathrm{l} \mathrm{NP-O-SU}$ $(7 \mathrm{~g} / 100 \mathrm{ml}$ of DMSO) in the flank on day 21 of genistein treatment. Six days after sensitization, mice were challenged by injecting $25 \mu \mathrm{l} \mathrm{NP-O-SU}(2 \mathrm{~g} / 100 \mathrm{ml}$ of DMSO) into the right footpad, while a control solution of DMSO and PBS vehicles was injected into the left footpad. One day later, the thickness of left and right footpads was measured in triplicate using a peacock dial gauge. The injection of the second dose of hapten induced a pronounced inflammatory response in the right foot, while the left foot did not show this response and served as the control. The results are expressed as the difference in footpad thickness between the right and left feet by subtracting left footpad thickness from that of the right. If a treatment decreases cell-mediated immunity, the difference between the right and left feet in these animals will be reduced compared with controls, while an increase in the difference between right and left feet would indicate increased cell-mediated immunity. Following the footpad measurements, animals were killed and both footpads were processed for histopathology.

Popliteal lymph nodes, the draining lymph nodes of the footpad, were collected from the hapten-injected limb of the animals that were injected with $80 \mathrm{mg} / \mathrm{kg}$ genistein or the vehicle control. The popliteal nodes were also collected from animals given dietary genistein at 0,1000 or $1500 \mathrm{ppm}$. A single cell suspension was made for flow cytometric analysis of $\mathrm{CD}^{+}{ }^{+}$and $\mathrm{CD} 8^{+} \mathrm{T}$ cells. Direct immunofluorescence was used to analyze lymphocyte subpopulations in these nodes using FITC-conjugated anti-mouse CD4 (L3T4 Pharmingen, San Diego, CA, USA) monoclonal antibody and phycoerythrin-conjugated 
anti-mouse CD8 (LY-2, Pharmingen) monoclonal antibody, as we have described (Yellayi et al. 2002).

Reversibility of the effects of genistein on cell-mediated immune responses

The reversibility of the effects of genistein on cellmediated immune responses was determined by measuring the DTH response in mice that had been given genistein treatment followed by a recovery period without genistein exposure. Mice were injected with DMSO or genistein (20 or $80 \mathrm{mg} / \mathrm{kg}$ body weight) for 28 days. All groups were then allowed to recover for an additional 28 days, then cell-mediated immunity was measured. All mice were sensitized by s.c. injection of $0.05 \mathrm{ml} \mathrm{NP-O}-$ $\mathrm{SU}$, as above, on day 21 following cessation of genistein treatment. Six days after sensitization, mice were challenged with NP-O-SU, then footpad thickness in both feet was determined $24 \mathrm{~h}$ later, as above.

\section{Statistical analysis}

Results were expressed as means \pm S.E.M., and the $n$ values for the various groups are given in the figure legends. Data were analyzed by one-way ANOVA followed by the Student-Newman-Keuls Multiple Comparisons test, and differences were considered significant at $P<0 \cdot 05$. In experiments involving only a control and a treated group, results were compared by Student's $t$-test.

\section{Results}

Genistein injections $(8-80 \mathrm{mg} / \mathrm{kg})$ in mice produced 46-67\% decreases in footpad thickness compared with controls (Fig. 1). In mice treated with genistein $(80 \mathrm{mg} /$ $\mathrm{kg} /$ day)+ICI 182,780 , the anti-estrogen partially reversed the genistein effects such that differences in footpad thickness were greater than in mice treated with genistein alone. However, differences in mean footpad thickness were not restored to normal in mice given genistein + ICI 182,780 , indicating that ICI 182,780 only partially blocked genistein's effects on the DTH response. In contrast, uterine weights in the genistein $(80 \mathrm{mg} / \mathrm{kg} /$ day)+ICI 182,780 group were totally inhibited and not different from those of control mice that did not receive genistein (not shown).

The observed effects of genistein on footpad thickness were corroborated by histopathological analysis of feet from the various groups (Fig. 2). Extensive cell infiltration was seen in right feet from control animals, typical of a robust DTH response (Fig. 2A). Cell infiltration was markedly reduced in right feet from mice treated with genistein $(80 \mathrm{mg} / \mathrm{kg})$, while the anti-estrogen ICI 182,780 partially reversed this genistein effect (Fig. $2 \mathrm{~B}$ and C respectively).

Dietary genistein treatment for 28 days resulted in a diminished DTH response compared with control animals

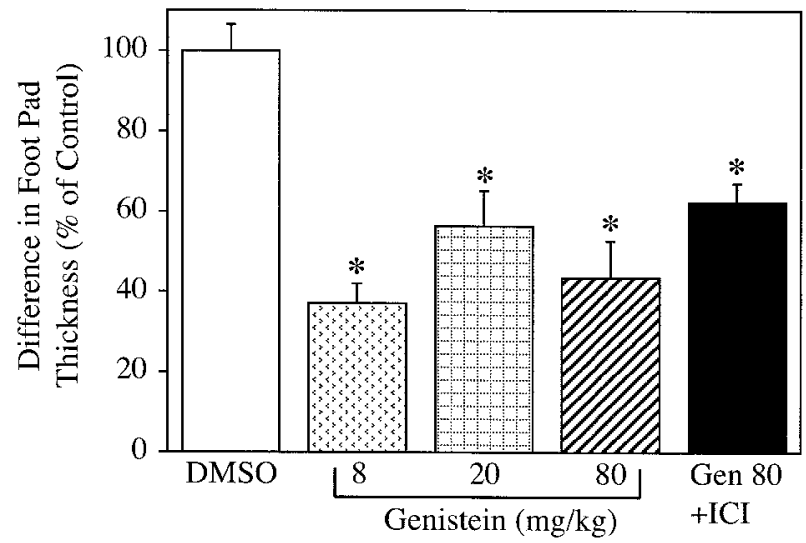

Figure 1 Effect of injected genistein on the DTH response. Ovariectomized mice (32- to 34-days-old at initiation of treatment) were given 28 daily subcutaneous injections of DMSO or genistein $(8-80 \mathrm{mg} / \mathrm{kg}$ ). Some mice given $80 \mathrm{mg} / \mathrm{kg}$ genistein were also given $\mathrm{ICl} 182,780$. Mice were sensitized on day 21 and challenged on day 27 with NP-O-SU, then footpad thickness was measured one day later. Data are presented as means \pm S.E.M. and are expressed as a percentage of control; $n=5-9$ for all points. All genistein treatments significantly $\left({ }^{*}\right)$ decreased the DTH response compared with controls $(P<0 \cdot 05)$. The 8,20 and $80 \mathrm{mg} / \mathrm{kg}$ genistein groups were not significantly different from each other, but footpad thickness in the genistein $+\mathrm{ICl} 182,780$ group was significantly greater than the $80 \mathrm{mg} / \mathrm{kg}$ genistein group.

that had received only the phytoestrogen-free diet without genistein supplementation (Fig. 3). Although the overall diminution in the DTH response was not as pronounced as those seen following injections of high levels of genistein, the overall DTH response was decreased almost 50\% in mice given 1000 or $1500 \mathrm{ppm}$ of genistein.

The numbers of both CD4 ${ }^{+}$(Fig. 4a) and $\mathrm{CD}^{+}$(Fig. 4b) $\mathrm{T}$ cells in the popliteal lymph nodes of mice fed genistein at either 1000 or $1500 \mathrm{ppm}$ for 28 days were reduced approximately $50 \%$ compared with those in control mice. Numbers of CD $4^{+}$and $\mathrm{CD}^{+} \mathrm{T}$ cells in the popliteal lymph nodes of mice injected with $80 \mathrm{mg} / \mathrm{kg}$ genistein were decreased approximately $75 \%$ for both cell types compared with the vehicle control (data not shown). Thus, in addition to the attenuated DTH response following genistein treatment, lymphocyte populations in the popliteal lymph nodes of these animals were decreased.

The genistein effects on cell-mediated immunity were rapidly reversed following cessation of this treatment (Fig. 5). Twenty-eight days after termination of genistein treatment, cell-mediated immunity had recovered even in mice given a high dose $(80 \mathrm{mg} / \mathrm{kg} /$ day $)$ of genistein.

\section{Discussion}

Our results show that injected genistein reduces the DTH response, indicating decreased cell-mediated immunity in 

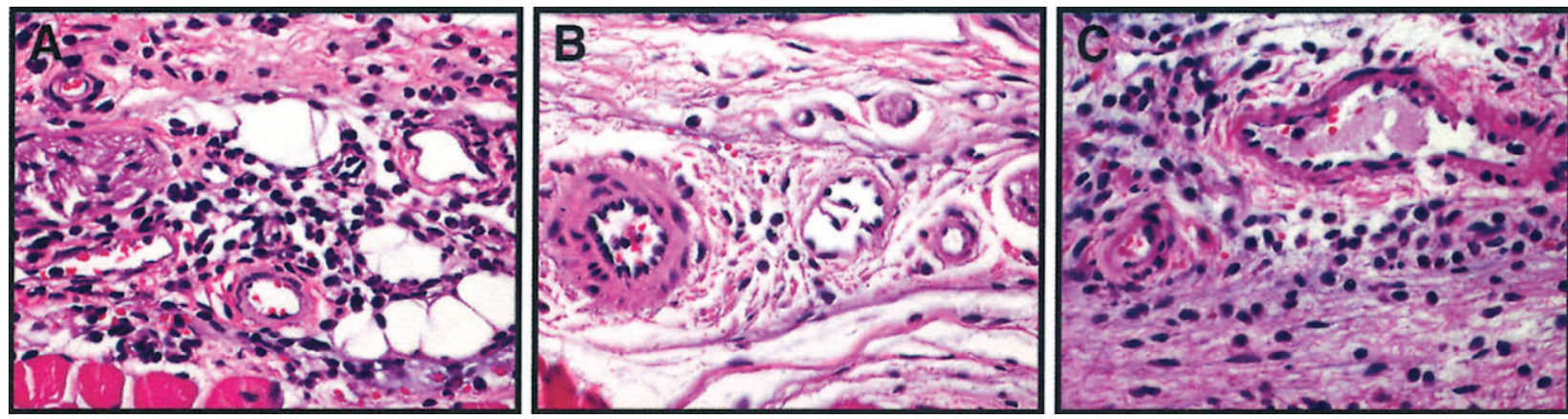

Figure 2 Histopathological comparison of the DTH response in the right footpad of mice that had been treated for 28 days with (A) DMSO (control), (B) genistein $(80 \mathrm{mg} / \mathrm{kg} /$ day) or (C) genistein $(80 \mathrm{mg} / \mathrm{kg} /$ day $)+$ the anti-estrogen $\mathrm{ICl} 182,780$. The extensive cell infiltration seen in right feet from control animals was markedly reduced in right feet from mice treated with genistein $(80 \mathrm{mg} / \mathrm{kg}), \mathrm{while}$ the anti-estrogen ICI 182,780 partially reversed this genistein effect. (Hematoxylin and eosin stain; magnification of all pictures $\times 400$.)

these animals. This decrease is similar to the decrease in humoral immunity that we recently reported following genistein injections (Yellayi et al. 2002), showing that genistein has suppressive effects on both the cell-mediated and humoral components of the adaptive immune system. It is well known that $\mathrm{E}_{2}$ suppresses cell-mediated immunity in mice and women (Holmdahl \& Jansson 1988, Hoek et al. 1995, Salem et al. 2000). The present results are the first data indicating that phytoestrogens such as genistein can produce similar decreases, although the $85 \%$ decreases

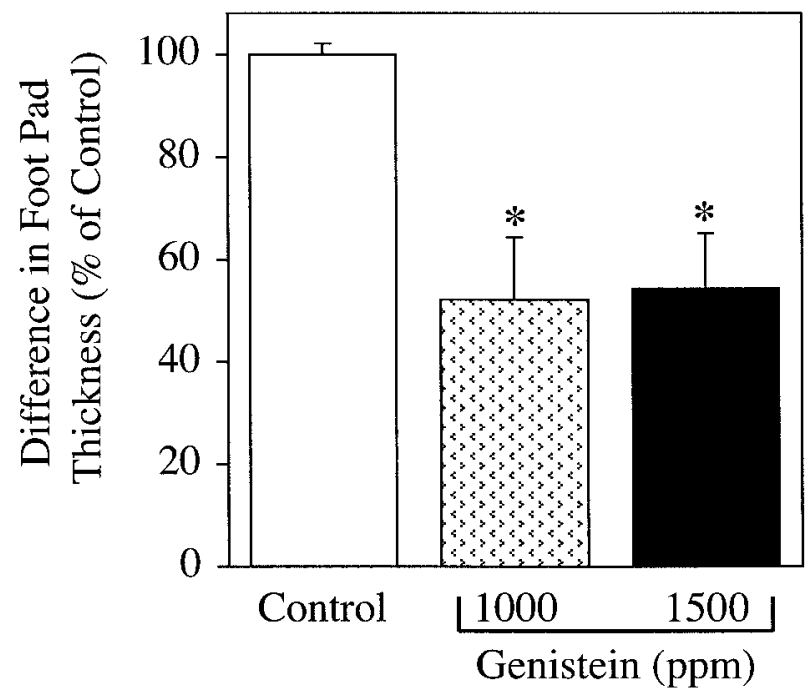

Figure 3 Effect of dietary genistein on the DTH response. Ovariectomized mice (32- to 34-days-old at initiation of treatment) were fed for 28 days with a phytoestrogen-free diet (control) or this diet supplemented with genistein (1000 or 1500 ppm). DTH sensitization and challenge were performed as in Fig. 1. Mice given genistein at both 1000 and 1500 ppm had significantly $\left(^{*}\right)$ decreased DTH responses compared with controls, but the genistein groups were not different from each other $(P<0 \cdot 05)$ Data are means \pm S.E.M. and are expressed as a percentage of control; $n=4-5$ for all points. in the DTH response seen with $\mathrm{E}_{2}$ (Salem et al. 2000) were more pronounced than those observed here.

Our previous work demonstrated that dietary genistein decreased thymic weight but effects on immune function were not examined. Our present findings indicate that in addition to decreasing thymic weight, dietary genistein is capable of decreasing cell-mediated immunity. These results are consistent with the recent report that either a high-soy diet or intravenous genistein could delay the rejection of rat cardiac allografts, which also indicates that genistein can have immunosuppressive properties in vivo (O'Connor et al. 2002).

Genistein binds to both ER $\alpha$ and ER $\beta$, and estrogenic effects of genistein have been reported on reproductive and other organs (Kuiper et al. 1998, Whitten \& Patisaul 2001). The thymus expresses both forms of ER, and ER $\alpha$ has been shown to be involved in thymic development (Kuiper et al. 1997, Yellayi et al. 2000, Erlandsson et al. 2001). Our previous results showing that genistein reduces the number of developing $\mathrm{CD}^{+}$and $\mathrm{CD}^{+}$thymocytes suggests that this could be one mechanism for genistein effects on cell-mediated immunity (Yellayi et al. 2002). In addition, peripheral $\mathrm{CD}^{+}$and $\mathrm{CD} 8^{+} \mathrm{T}$ cells and macrophages all express ER (Cohen et al. 1983, Gulshan et al. 1990, Suenaga et al. 1998), and estrogen has been shown to modulate the activities of these cell types (Ansar Ahmed et al. 1985, Dean et al. 1986, Cutolo et al. 1995).

Treatment of mice with the anti-estrogen ICI 182,780 did not completely restore the genistein-induced decreases seen in the DTH response. We have previously examined the effects of genistein on thymic atrophy, adipose deposition and uterine weight in mice (A Naaz \& P S Cooke, unpublished data; Yellayi et al. 2002). Dietary genistein produces decreases in thymic weight at $1000 \mathrm{ppm}$ or above (Yellayi et al. 2002), but does not produce thymic effects at $500 \mathrm{ppm}$ or lower (A Naaz \& P S Cooke, unpublished data). Genistein produces effects on adipose tissue at $500 \mathrm{ppm}$ or above, while uterotropic effects of 

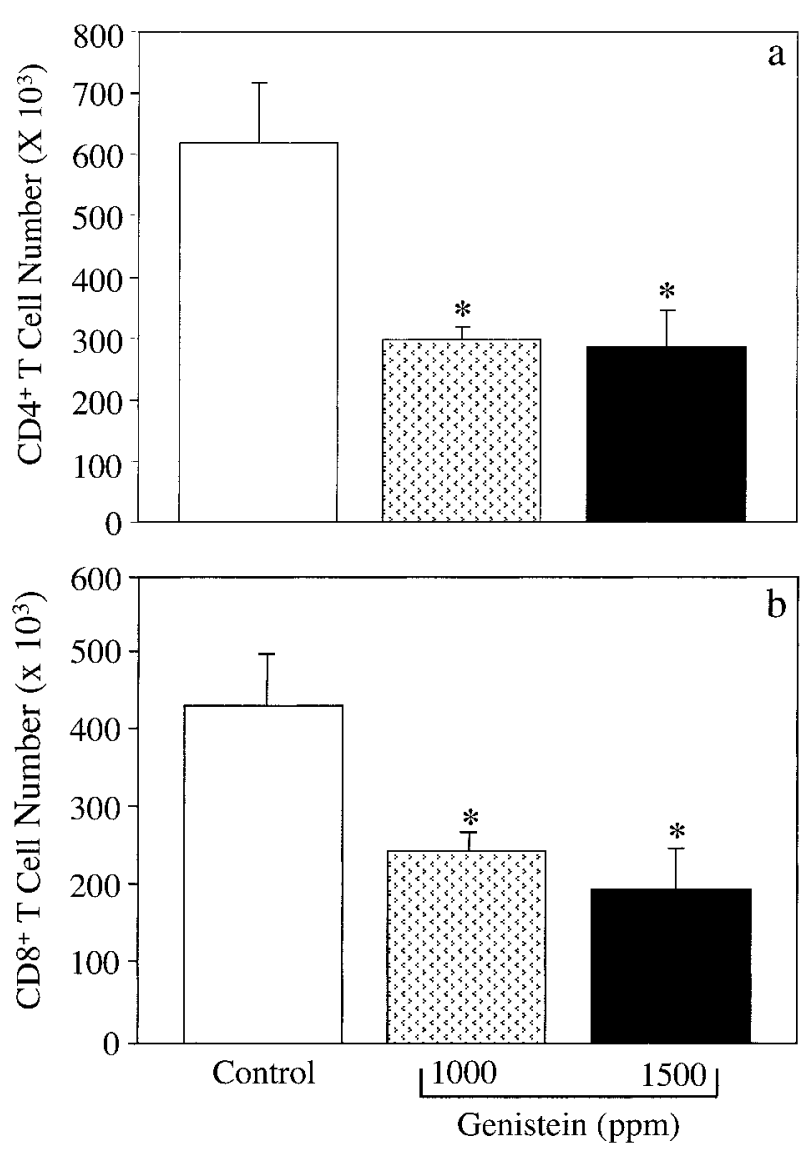

Figure 4 Effect of genistein on $\mathrm{CD}^{+}$and $\mathrm{CD}^{+} \mathrm{T}$ cells numbers in the popliteal lymph nodes. Numbers of (a) $\mathrm{CD}^{+}$and (b) $\mathrm{CD} 8^{+}$ $\mathrm{T}$ cells in the popliteal lymph nodes of the right limb of mice fed for 28 days with the phytoestrogen-free diet (control), or this diet supplemented with genistein. When genistein was given at either 1000 and 1500 ppm, there were significant $\left(^{*}\right)$ decreases in both $\mathrm{CD}^{+}$and $\mathrm{CD}^{+}{ }^{+}$cell numbers compared with the control, but the genistein groups were not significantly different from each other $(P<0 \cdot 05)$. Data are means \pm S.E.M. and are expressed as a percentage of control; $n=4-5$ for all points. The lymph node data shown in this figure was obtained from the same mice used for the DTH results shown in Fig. 3.

genistein are seen at $300 \mathrm{ppm}$ or above. Similar results have been seen with injected genistein, where a $2 \mathrm{mg} /$ $\mathrm{kg} /$ day dose produces uterotropic effects even though no thymic effects are seen with this dose (Yellayi et al. 2002). Thus, the uterotropic effect of genistein is the most sensitive indicator of estrogenic genistein actions. Based on the ability of ICI 182,780 to block the typical uterine weight increase induced by genistein, we concluded that the ICI 182,780 completely inhibits ER-mediated effects, and that effects on cell-mediated immunity seen here even in the presence of ICI 182,780 were not mediated through ER.

Genistein inhibits protein tyrosine kinases, topoisomerase II and certain other cellular processes through non-

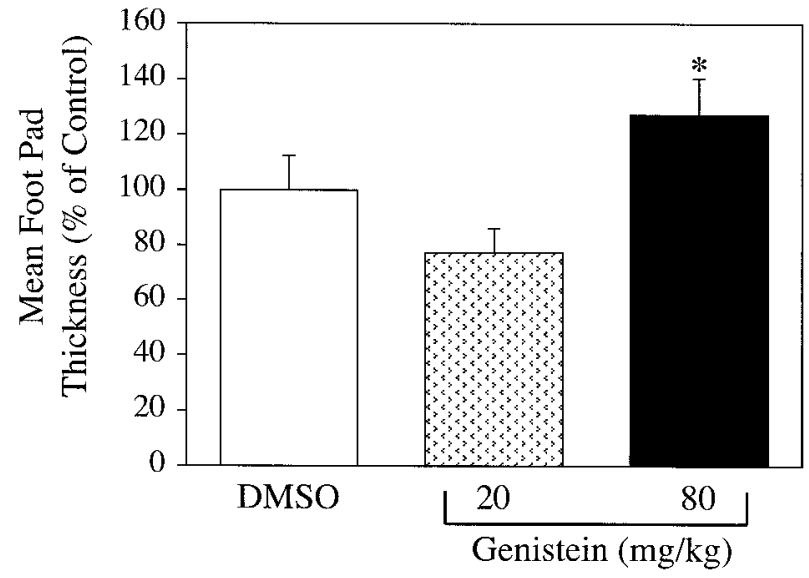

Figure 5 Recovery of the DTH response following cessation of genistein treatment. Ovariectomized mice (32- to 34-days-old at initiation of treatment) were given 28 daily subcutaneous injections of DMSO or genistein ( 20 or $80 \mathrm{mg} / \mathrm{kg}$ ). They were then allowed to recover for 28 days. Mice were sensitized on day 21 of recovery with NP-O-SU, then challenged 6 days later with NP-O-SU, and footpad thickness was measured one day later, which was day 28 of recovery. Data are means \pm S.E.M. and are expressed as a percentage of control; $n=6-8$ for all points. The control and $20 \mathrm{mg} / \mathrm{kg}$ genistein groups were not significantly different, but the mean footpad thickness in the $80 \mathrm{mg} / \mathrm{kg}$ genistein group was significantly greater than the control $(P<0 \cdot 05)$.

ER-mediated mechanisms (reviewed in Adlercreutz 1998, Patisaul \& Whitten 1999); these non-ER-mediated pathways appear to contribute to the genistein effects on cell-mediated immunity. The incomplete blockage of the inhibitory effects of genistein on cell-mediated immunity by ICI 182,780 is similar to that seen with genistein effects on thymic atrophy (Yellayi et al. 2002), indicating that the effects of genistein on both processes involve both ERmediated and non-ER-mediated components. Consistent with this finding, Guo et al. (2002) have recently shown that the thymic changes resulting from feeding genistein to rats during gestation and lactation were not entirely the result of estrogenic effects. Therefore, the ability of genistein to induce thymic and immune effects appears to involve non-ER-mediated components in both rats and mice.

Previous results have indicated that $\mathrm{E}_{2}$ treatment of adult mice decreases leukocyte numbers in the draining lymph nodes from the injected limb in the DTH response (Salem et al. 2000). The measurements of $\mathrm{CD}^{+}$and $\mathrm{CD}^{+} \mathrm{T}$ cell numbers in the popliteal lymph nodes of control and genistein-treated mice indicate that both of these cell types are significantly reduced following genistein treatment. The decreased $\mathrm{T}$ cell numbers may be a critical aspect of the mechanism by which genistein produces decreased inflammation and the attenuated DTH response, although other changes (e.g. decreased $\mathrm{T}$ cell function) could be involved. The decreased lymph node 
$\mathrm{T}$ cell populations reported here are consistent with the decreased thymocyte numbers and $\mathrm{T}$ cell numbers in the thymus and spleen respectively following genistein treatment (Yellayi et al. 2002).

Genistein injected at doses of 20 or $80 \mathrm{mg} / \mathrm{kg} /$ day for 21 days causes decreases in thymic weight of $40 \%$ and $70 \%$ respectively (Yellayi et al. 2002), and impairs cellmediated and humoral immunity. Despite the marked genistein effects on thymic size and immune function, cell-mediated immunity recovers to normal when these treatments are stopped and the mice recover for 28 days. Thymic weight also recovers to normal (data not shown). Thus, thymic and immune changes induced by adult exposure to genistein are reversible. Perinatal estrogen treatment can have permanent immune effects in mice and humans (Luster et al. 1979), but the immune effects caused by estrogen exposure at older ages tend to be reversible. For example, high levels of estrogen cause decreased thymic size during pregnancy, but thymic size returns to normal post-partum (Rijhsinghani et al. 1997). Likewise, suppression of thymic size by $\mathrm{E}_{2}$ or diethystilbestrol in juvenile and adult animals is reversible, usually by $2-4$ weeks after treatment (Barnes et al. 1983, Forsberg 1996). Therefore, the observed recovery in cell-mediated immunity after genistein treatment is consistent with the reversibility of suppressive estrogenic effects on the immune system reported previously.

Interestingly, the cell-mediated immune response in mice treated with genistein $80 \mathrm{mg} / \mathrm{kg} /$ day then allowed to recover for 28 days was actually greater than the controls, indicating that there may be a temporary overshoot of normal values in this parameter during recovery. This type of phenomenon has also been described previously following estrogen treatment (Forsberg 1996).

While our present studies used genistein alone, the dietary soy in food consumed by humans and animals is mostly in the form of soy protein isolate or soy flour. Both of these products are compound mixtures that contain other isoflavones in addition to genistein, as well as other bioactive compounds. These other ingredients could potentially have additive or inhibitory effects on genistein's ability to produce thymic and immune effects, so it remains to be established whether soy protein isolate or soy flour would have the same effects as genistein alone.

Rodents metabolize genistein faster than humans (Holder et al. 1999, Chang et al. 2000, Ju et al. 2001). Although equal levels of genistein consumption on a body weight basis in rodents and humans produce very different serum genistein levels, these interspecies metabolic differences can be negated by feeding higher levels of genistein. This allows experimental serum genistein concentrations to be obtained that are equivalent to humans in various nutritional situations, as demonstrated previously by Chang and colleagues (2000) in the rat. Serum genistein levels in mice fed 1000 and $1500 \mathrm{ppm}$ genistein were $2 \cdot 5$ and $3 \cdot 8 \mu \mathrm{M}$ respectively ( $\mathrm{Naaz}$ et al. unpublished results).
These levels exceed serum genistein levels in Japanese men $($ mean $=0.38 \mu \mathrm{M})$ whose diets have historically included soy products (Adlercreutz 1998). However, consumption of one meal containing soymilk or soy/isoflavone supplements by humans produces peak serum genistein concentrations of up to $5 \mu \mathrm{M}$ (Xu et al. 1995, Djuric et al. 1999), and human infants fed soy-based formula have serum genistein concentrations ranging from 1.5-4.4 $\mu \mathrm{M}$ (Setchell et al. 1997). Serum genistein concentrations in mice fed 1000-1500 ppm genistein exceed those in human populations eating high-soy diets, but there are a number of situations where humans have serum genistein concentrations comparable to those reported here for mice fed genistein

The ability of serum genistein levels obtained in humans to induce changes in cell-mediated immunity in mice suggests the possibility of potential risk to humans under certain nutritional conditions. However, it must be emphasized that a critical question that remains to be answered is whether these results are relevant for humans or animals consuming high levels of isoflavones. The complexity of this question is clearly illustrated by recent work of Guo and colleagues which showed that rat dams exposed to genistein beginning early in gestation had decreased thymic weight on day 22 postpartum after exposure to $800 \mathrm{ppm}$ genistein (Guo et al. 2002b) but there was no effect on thymic weight on postpartum day 51 in a subsequent study even when dams were exposed to up to $1250 \mathrm{ppm}$ genistein (Guo et al. 2002a). In addition, there were variations in the responses of the dams vs the pups, and male vs female pups (Guo et al. 2002a). These results indicate that the effects of genistein on immune parameters can vary depending on the species, length of exposure, and the age and sex of the animal. Thus, extrapolation of results from one species to others, and especially potential extrapolation of rodent studies to humans, must be approached with the greatest caution.

Present literature on a possible link between high levels of soy consumption and immune impairments is contradictory. There are previous reports that $\mathrm{T}$ cell function, gamma globulin and immunoglobulins were decreased in infants fed soy formula compared with cow milk formulafed controls (Zoppi et al. 1979, 1982). Soy-fed infants had reduced titers of antibodies against polio, tetanus, diphtheria and pertussis and increased morbidity compared with infants fed cow milk formula (Zoppi et al. 1982, 1983). In contrast, two recent companion papers did not confirm the extensive immune abnormalities described in the initial studies and reported that a number of parameters related to immune cell populations, vaccine response and morbidity were within the normal range in soy-fed infants (Cordle et al. 2002, Ostrom et al. 2002). There were some differences in soy preparations, experimental methodologies and endpoints in these two groups of studies, but an explanation for the diametrically opposite conclusions obtained by the two groups is not obvious. 
Therefore, a firm conclusion regarding immune effects of soy formula on human infants is difficult to reach. Even if subsequent work demonstrates conclusively that soy formula does not impair average immune function in large groups of infants, the possibility of immune effects in certain subsets of infants must still be considered. Serum isoflavone concentrations in soy-fed infants show about a threefold range, indicating that some infants may digest and/or absorb isoflavones more efficiently than others, or may metabolize these compounds more slowly (Setchell et al. 1997). In addition, only about $30-40 \%$ of humans are able to metabolize daidzein to the more potent estrogen equol (Adlercreutz 1998), and we have recently shown that equol injected for 7 days at $20 \mathrm{mg} / \mathrm{kg}$ produces a $25 \%$ decrease in thymic weight (P S Cooke, unpublished data). We have shown that female mice are more responsive than males to the thymic effects of genistein (Yellayi et al. 2002), and peak serum genistein concentrations are higher in females compared with males when both are given the same amount of genistein (Doerge et al. 2002), suggesting that female infants might be more susceptible to immune effects of genistein than male infants. Therefore, subsets of infants with greater isoflavone responsiveness, higher isoflavone concentrations and/or those who make equol may be more susceptible to thymic/immune effects of isoflavones and potentially show immune effects even if a suppression of average immune function in large populations of soy-fed infants is not seen.

Most commercial rodent diets contain high amounts of soy and isoflavones (Boettger-Tong et al. 1998, Thigpen et al. 1999), and recent work by Brown and Setchell (2001) reported up to $830 \mu \mathrm{g} / \mathrm{kg}$ total isoflavones in widely-used commercial chows. In addition, rodents fed soy-based diets have circulating isoflavone levels of up to $8.5 \mu \mathrm{M}$ (Brown \& Setchell 2001), which equals or exceeds those reported to cause thymic and immune suppression in mice in our studies. Although the majority of the plasma isoflavone was equol rather than genistein in these animals, our preliminary results show that injected equol is similar to genistein in its ability to induce thymic atrophy. Thus, feeding mice normal commercial diets containing high amounts of soy could potentially have immune effects, and this needs further investigation.

Some commercial dog and cat diets contain high levels of soy isoflavones, and food animals such as swine are fed high levels of soy, beginning at weaning (Cook 1998, Court \& Freeman 2002). Total isoflavone intake of cats consuming these diets can be up to $4.5 \mathrm{mg} / \mathrm{kg} /$ day (Court \& Freeman 2002), in the range of isoflavone consumption by human infants fed soy-based formula (Setchell et al. 1997). Cats have a significantly reduced capacity to metabolize and excrete compounds such as isoflavones by glucuronidation (Court \& Greenblatt 2000) and infertility and a veno-occlusive disease have been reported in another felid, the cheetah, fed a high-soy diet (Setchell et al. 1987). Serum concentrations of isoflavones such as genistein have not been reported in cats fed commercial cat foods, but the combination of their high isoflavone consumption and decreased capacity to metabolize and excrete these compounds indicates they may reach serum genistein levels above those shown here to produce decreased cell-mediated immunity in mice, although whether this would produce immune effects in cats or other species consuming high levels of soy remains to be investigated.

In summary, injected and dietary genistein can impair cell-mediated immunity in mice. The relevance of these findings to humans and laboratory, companion and food animals is uncertain, but the serum genistein concentrations that produce these effects in mice can be obtained in humans and animals under various nutritional conditions.

\section{Acknowledgements}

This work was supported by grants from the United Soybean Board and Illinois Council on Food and Agricultural Research (CFAR).

\section{References}

Adlercreutz H 1998 Human health and phytoestrogens. In Reproductive and Developmental Toxicology, pp 299-371. Ed. K Korach. New York: Marcel Dekker.

Ansar Ahmed S, Dauphinee MJ \& Talal N 1985 Effects of short-term administration of sex hormones on normal and autoimmune mice. Journal of Immunology 134 204-210.

Barnes DW, Page DG, Duke SS \& White KL 1983 Subchronic toxicology of diethystilbestrol in the mouse. Drug and Chemical Toxicology 6 455-485.

Boettger-Tong H, Murthy L, Chiappetta C, Kirkland JL, Goodwin B, Adlercreutz H, Stancel GM \& Makela S 1998 A case of a laboratory animal feed with high estrogenic activity and its impact on in vivo responses to exogenously administered estrogens [see comments]. Environmental Health Perspectives 106 369-373.

Brown NM \& Setchell KD 2001 Animal models impacted by phytoestrogens in commercial chow: implications for pathways influenced by hormones. Laboratory Investigation 81 735-747.

Chang HC, Churchwell MI, Delclos KB, Newbold RR \& Doerge DR 2000 Mass spectrometric determination of genistein tissue distribution in diet-exposed Sprague-Dawley rats. Journal of Nutrition 130 1963-1970.

Cohen JH, Danel L, Cordier G, Saez S \& Revillard JP 1983 Sex steroid receptors in peripheral $\mathrm{T}$ cells: absence of androgen receptors and restriction of estrogen receptors to OKT8-positive cells. Journal of Immunology 131 2767-2771.

Cook DR 1998 The effect of dietary soybean isoflavones on the rate and efficiency of growth and carcass muscle content in rats. Iowa State University, Ames.

Cordle CT, Winship TR, Schaller JP, Thomas DJ, Buck RH, Ostrom KM, Jacobs JR, Blatter MM, Cho S, Gooch WM \& Pickering LK 2002 Immune status of infants fed soy-based formulas with or without added nucleotides for 1 year. Part 2: immune cell populations. Journal of Pediatric Gastroenterology and Nutrition 34 137-144.

Court MH \& Greenblatt DJ 2000 Molecular genetic basis for deficient acetaminophen glucuronidation by cats: UGT1A6 is a pseudogene, and evidence for reduced diversity of expressed hepatic UGT1A isoforms. Pharmacogenetics 10 355-369. 
Court MH \& Freeman LM 2002 Identification and concentration of soy isoflavones in commercial cat foods. American Journal of Veterinary Research 63 181-185.

Cutolo M, Sulli A, Seriolo B, Accardo S \& Masi AT 1995 Estrogens, the immune response and autoimmunity. Clinical and Experimental Rheumatology 13 217-226.

Dean JH, Lauer LD, Murray MJ, Luster MI, Neptun D \& Adams DO 1986 Functions of mononuclear phagocytes in mice exposed to diethylstilbestrol: a model of aberrant macrophage development. Cellular Immunology 102 315-322.

Djuric Z, Sarkar F, Redd JN \& Kucuck O 1999 Effect of soy isoflavone dietary supplementation on levels of oxidation DNA damage in blood of women. The Toxicologist 48204.

Doerge DR, Twaddle NC, Banks EP, Jefferson WN \& Newbold RR 2002 Pharmokinetic analysis in serum of genistein administered subcutaneously to neonatal mice. Cancer Letters 184 21-27.

Erlandsson MC, Ohlsson C, Gustafsson JA \& Carlsten H 2001 Role of oestrogen receptors alpha and beta in immune organ development and in oestrogen-mediated effects on thymus. Immunology 103 $17-25$.

Forsberg JG 1996 The different responses of the female mouse thymus to estrogen after treatment of neonatal, prepubertal, and adult animals. Acta Anatomica 157 275-290.

Gulshan S, McCruden AB \& Stimson WH 1990 Oestrogen receptors in macrophages. Scandinavian Journal of Immunology 31 691-697.

Guo TL, White KL Jr, Brown RD, Delclos KB, Newbold RR, Weis C, Germolec DR \& McCay JA 2002a Genistein modulates splenic natural killer cell activity, antibody-forming cell response, and phenotypic marker expression in $\mathrm{F}(0)$ and $\mathrm{F}(1)$ generations of Sprague-Dawley rats. Toxicology and Applied Pharmacology 181 219-227.

Guo TL, Zhang XL, Bartolucci E, McCay JA, White KL Jr \& You L $2002 b$ Genistein and methoxychlor modulate the activity of natural killer cells and the expression of phenotypic markers by thymocytes and splenocytes in F0 and F1 generations of Sprague-Dawley rats. Toxicology 172 205-215.

Hoek A, van Kasteren Y, de Haan-Meulman M, Hooijkaas H, Schoemaker J \& Drexhage HA 1995 Analysis of peripheral blood lymphocyte subsets, NK cells, and delayed type hypersensitivity skin tests in patients with premature ovarian failure. American Journal of Reproductive Immunology and Microbiology 33 495-502.

Holder CL, Churchwell MI \& Doerge DR 1999 Quantification of soy isoflavones, genistein and daidzein, and conjugates in rat blood using LC/ES-MS. Journal of Agricultural and Food Chemistry 47 3764-3770.

Holmdahl R \& Jansson L 1988 Estrogen-induced suppression of collagen arthritis. III. Adult thymectomy does not affect the course of arthritis or the estrogen-mediated suppression of T-cell immunity. Brain Behaviour and Immunity 2 123-132.

Ju YH, Allred CD, Allred KF, Karko KL, Doerge DR \& Helferich WG 2001 Physiological concentrations of dietary genistein dosedependently stimulate growth of estrogen-dependent human breast cancer (MCF-7) tumors implanted in athymic nude mice. Journal of Nutrition 131 2957-2962.

Kuiper GG, Carlsson B, Grandien K, Enmark E, Haggblad J, Nilsson S \& Gustafsson JA 1997 Comparison of the ligand binding specificity and transcript tissue distribution of estrogen receptors alpha and beta. Endocrinology 138 863-870.

Kuiper GG, Lemmen JG, Carlsson B, Corton JC, Safe SH, van der Saag PT, van der Burg B \& Gustafsson JA 1998 Interaction of estrogenic chemicals and phytoestrogens with estrogen receptor beta. Endocrinology 139 4252-4263.

Luster MI, Faith RE, McLachlan JA \& Clark GC 1979 Effect of in utero exposure to diethylstilbestrol on the immune response in mice. Toxicology and Applied Pharmacology 47 279-285.

O’Connor TP, Liesen DA, Mann PC, Rolando L \& Banz WJ 2002 A high isoflavone soy protein diet and intravenous genistein delay rejection of rat cardiac allografts. Journal of Nutrition 132 2283-2287.
Ostrom KM, Cordle CT, Schaller JP, Winship TR, Thomas DJ, Jacobs JR, Blatter MM, Cho S, Gooch WM, Granoff DM, Faden H \& Pickering LK 2002 Immune status of infants fed soy-based formulas with or without added nucleotides for 1 year. Part 1 : vaccine responses and morbidity. Journal of Pediatric Gastroenterology and Nutrition 34 137-144.

Patisaul HB \& Whitten PL 1999 Dietary phytoestrogens. In Endocrine Disruptors, pp 89-124. Ed. RK Naz. Boca Raton: CRC Press.

Rijhsinghani A, Bhatia SK, Kantamneni L, Schlueter A \& Waldschmidt TJ 1997 Estrogen inhibits fetal thymocyte development in vitro. American Journal of Reproductive Immunology 37 384-390.

Salem ML, Matsuzaki G, Kishihara K, Madkour GA \& Nomoto K 2000 Beta-estradiol suppresses T cell-mediated delayed-type hypersensitivity through suppression of antigen-presenting cell function and Th1 induction. International Archives of Allergy and Applied Immunology 121 161-169.

Setchell KD, Gosselin SJ, Welsh MB, Johnston JO, Balistreri WF, Kramer LW, Dresser BL \& Tarr MJ 1987 Dietary estrogens - a probable cause of infertility and liver disease in captive cheetahs. Gastroenterology 93 225-233.

Setchell KD, Zimmer-Nechemias L, Cai J \& Heubi JE 1997 Exposure of infants to phyto-oestrogens from soy-based infant formula. Lancet $35023-27$.

Sharpe RM, Martin B, Morris K, Greig I, McKinnell C, McNeilly AS \& Walker M 2002 Infant feeding with soy formula milk: effects on the testis and on blood testosterone levels in marmoset monkeys during the period of neonatal testicular activity. Human Reproduction 17 1692-1703.

Suenaga R, Evans MJ, Mitamura K, Rider V \& Abdou NI 1998 Peripheral blood $\mathrm{T}$ cells and monocytes and $\mathrm{B}$ cell lines derived from patients with lupus express estrogen receptor transcripts similar to those of normal cells. Journal of Rheumatology 25 1305-1312.

Thigpen JE, Setchell KD, Ahlmark KB, Locklear J, Spahr T, Caviness GF, Goelz MF, Haseman JK, Newbold RR \& Forsythe DB 1999 Phytoestrogen content of purified, open- and closed-formula laboratory animal diets. Laboratory Animal Science 49 530-536.

Whitten PL \& Patisaul HB 2001 Cross-species and interassay comparisons of phytoestrogen action. Environmental Health Perspectives 109 Suppl 1 5-20.

Xu X, Harris KS, Wang HJ, Murphy PA \& Hendrich S 1995 Bioavailability of soybean isoflavones depends upon gut microflora in women. Journal of Nutrition 125 2307-2315.

Yellayi S, Teuscher C, Woods JA, Welsh THJ, Tung KS, Nakai M, Rosenfeld CS, Lubahn DB \& Cooke PS 2000 Normal development of thymus in male and female mice requires estrogen/estrogen receptor-alpha signaling pathway. Endocrine 12 207-213.

Yellayi S, Naaz A, Szewczykowski MA, Sato T, Woods JA, Chang J, Segre M, Allred CD, Helferich WG \& Cooke PS 2002 The phytoestrogen genistein induces thymic and immune changes: a human health concern? PNAS 99 7616-7621.

Zoppi G, Zamboni G, Bassani N \& Vazzoler G 1979 Gammaglobulin level and soy-protein intake in early infancy. European Journal of Pediatrics 131 61-69.

Zoppi G, Gerosa F, Pezzini A, Bassani N, Rizzotti P, Bellini P, Todeschini G, Zamboni G, Vazzoler G \& Tridente G 1982 Immunocompetence and dietary protein intake in early infancy. Journal of Pediatric Gastroenterology and Nutrition 1 175-182.

Zoppi G, Gasparini R, Mantovanelli F, Gobio-Casali L, Astolfi R \& Crovari P 1983 Diet and antibody response to vaccinations in healthy infants. Lancet 2 11-14.

Received in final form 7 October 2002

Accepted 4 November 2002 